\title{
The detection of circulating antibody in human toxocara infections using the indirect fluorescent antibody test
}

\author{
B. BISSERU AND A. W. WOODRUFF \\ From the Department of Clinical Tropical Medicine, London School of Hygiene and Tropical Medicine, and \\ the Hospital for Tropical Diseases, London
}

The indirect fluorescent antibody test has been used to detect Toxocara antibodies quantitatively in human sera. The results obtained correlate well with those obtained with the toxocara skin test. Cross reactions have been found with Ascaris lumbricoides and about one in five normal sera give a significant fluorescent reaction. The specificity of the test has been established by Ascaris adsorption studies and by a lack of cross reaction with sera from other helminthic infections. The test may be especially easy to use and therefore particularly valuable in regions where $A$. lumbricoides infection is relatively rare.

Infection with the second stage larva of Toxocara canis of the dog and $T$. cati of the cat constitutes an important clinical and public health problem in Britain and elsewhere, and the toxocara skin test antigen has been used for determining the incidence of past toxocaral infection in man (Woodruff and Thacker, 1964; Bisseru, Woodruff, and Hutchinson, 1966). The clinical diagnosis of toxocaral infection presents some difficulties as the second stage larvae migrating in the body cannot be recovered or detected, except by biopsy techniques. Experiments have therefore been carried out in the use of the fluorescent antibody technique for diagnosis of the infection in man and these are reported in this paper.

The fluorescent antibody technique has been used in recent years in the investigation of antibodies in protozoal and some helminthic infections. In the field of helminthology the indirect fluorescent antibody technique has been applied to the serodiagnosis of trichinosis, schistosomiasis, ascariasis, filariasis, and visceral larva migrans. Jackson (1959) used it to locate antigenic sites in Trichinella spiralis infections in rabbits. Sadun, Anderson, and Williams (1962) found the test reliable for the serological diagnosis of trichinosis in man. Sadun, Williams, and Anderson (1960), and Anderson, Sadun, and Williams (1961) found the method to be practicable in the laboratory diagnosis of schistosomiasis. Voller and Taffs (1962) and Taffs and Received for publication 16 October 1967.
Voller (1963) have shown both in vitro and in vivo that the third stage of Ascaris larvae of man and pig possess common antigens and a similar crossreaction was observed by the fluorescence of decoated eggs of the two species. Mitchell (1964) used the indirect fluorescent antibody test for the detection of $T$. canis antibodies in animals experimentally infected with $T$. canis or Ascaris suum and rabbits and monkeys inoculated or infected with various bacterial, viral and parasitic antigens. Moreover, Mitchell (1964) found that the sera of five out of 25 infants and 17 out of 49 normal adult blood donors gave a significant fluorescent reaction using $T$. canis second stage larvae as antigen. Hogarth-Scott (1966) used the second stage larvae of $T$. canis, $T$. cati, and Toxocaris leonina for the detection of antibodies in rabbit and human sera by the indirect immunofluorescent test.

\section{MATERIAL AND METHODS}

SECOND STAGE T. CANIS LARVAE AS ANTIGEN T. canis eggs were obtained from the faeces of puppies and dogs or were removed from the uteri of female worms. The eggs were placed in $1 \%$ formalin in universal bottles $8 \times$ $2.5 \mathrm{~cm}$, at room temperature (about $26^{\circ} \mathrm{C}$ ) and allowed to embryonate. When, after a minimum of 30 days, embryonation had taken place each mouse was infected with about 1,000 ova taken by mouth in ground-up dry feed and then killed 60 to 72 hours later. The larvae were recovered from the liver and brain by the Baermann technique and washed twice in normal saline. 
All material was preserved at $-20^{\circ} \mathrm{C}$ either in saline or $10 \%$ formol-saline. Larvae in saline were used as soon as possible after recovery and were discarded for test purposes six weeks after collection.

EGGS AS ANTIGEN Eggs recovered from the uteri of female worms were decoated using Milton (containing $1 \%$ sodium hypochloricle and $16.5 \%$ sodium chloride) according to the method of Taffs and Voller (1963). The outer albuminous coat was removed by placing eggs for five hours at $37^{\circ} \mathrm{C}$ in $80 \%$ Milton. The eggs were washed five times with $100 \mathrm{ml}$ of normal saline, decanting the supernatant each time to get rid of the excess Milton after the eggs had settled to the bottom of a conical flask. Embryonated eggs were treated in the same way and all eggs were preserved at $-20^{\circ} \mathrm{C}$.

Human sera were obtained from (1) a patient with toxocaral granuloma of the eye in which organ when enucleated the second stage larva of $T$. canis was demonstrated histologically. (2) A patient with a unilateral 'Toxocaral' granuloma of the eye and positive toxocara skin test in whom toxocariasis was strongly suspected on clinical grounds. (3) Nine patients in whom toxocara skin tests were positive. (4) Five patients who had had paralytic poliomyelitis and in whom toxocaral skin tests were positive. (5) Four patients with asthma and with positive toxocaral skin tests but with no reaction to gelatine or saline injected for control purposes. (6) Twenty-seven patients with negative toxocaral skin tests. (7) Forty-two specimens either from patients with suspected toxocaral infections from hospitals in Britain or from the Outpatient Department of the Hospital for Tropical Diseases. (8) Three patients with Ascaris lumbricoides infection, one of whom was also infected with Trichuris trichiura. (9) Sera also from patients with helminthic infections: onchocerciasis (2), schistosomiasis (2), Bancroftian filariasis (2), Trichuris trichiura (2), Acanthoceilonema perstans (1), Taenia saginata (1).

Sera inactivated by heating at $56^{\circ} \mathrm{C}$ for one hour were also tested and no difference was found in the intensity and endpoint of the fluorescence observed in sera from patients with toxocariasis or ascariasis.

FLUORESCENT STAINING The indirect fluorescent staining technique was used employing goat antihuman and rabbit antihuman globulins (Burroughs Wellcome \& $\mathrm{Co}$ ). Each millilitre of fluorescin-labelled antiserum was diluted to $12 \mathrm{ml}$ with phosphate-buffered saline and was adsorbed twice with $100 \mathrm{mg}$ of pigeon liver powder and centrifuged. The antiserum was stored at $-20^{\circ} \mathrm{C}$. Serial dilutions of sera were prepared with phosphate-buffered saline.

ADSORPTIONS Cross reacting fluorescence of $T$. canis larva was obtained with serum from patients with ascariasis; adsorption of such serum was carried out using a saline extract of dry powdered Ascaris lumbricoides worms. Whole worm was dried in a dessicator over calcium chloride for several days, powdered in a mortar, and weighed. A suspension of $2 \mathrm{mg} / \mathrm{ml}$ of saline was made, incubated overnight at $4^{\circ} \mathrm{C}$, filtered through Whatman no. 2 paper at room temperature and stored at $-20^{\circ} \mathrm{C}$.
The serum to be adsorbed was added directly to Ascaris extract in the following proportions:

1 volume test serum to 1 volume Ascaris extract

1 volume test serum to 2 volumes Ascaris extract

1 volume test serum to 3 volumes Ascaris extract

All preparations were incubated at room temperature fo one hour.

TEST PROCEDURE Serum diluted with phosphate buffered saline (PBS) was mixed in $8.5 \times 1 \mathrm{~cm}$ serologicas tubes and all tests were carried out at room temperature Between four and six larvae of $T$. canis or approximately 100 decoated eggs were added to the tubes containing test serum and mixed. High dilutions up to 40,000 were prepared, but in most instances a dilution of $1 / 80$ was used. An inhibition effect (prozone) was sometimes obis served with immune serum at lower dilutions $(1 / 10)$ so these lower dilutions were not employed when it was only wished to determine whether a serum reacted positivef ly or not. The larvae or decoated eggs were incubated foo 30 minutes and then washed twice with phosphate buffered saline, there being an interval of 15 minutes between washings to allow larvae or eggs to sediment to the bottom of the tube. Much of the phosphate-buffered saline was removed with a pasteur pipette after the second washing, taking care at the same time not to loseo the larvae or eggs. Of fluorescein-labelled rabbit or goat antihuman globulin, 0.06 to $0.08 \mathrm{ml}$ was added and the larvae or eggs were suspended for 30 minutes, afte which they were again washed twice with phosphate buffered saline with 15-minute intervals between washingso as much phosphate-buffered saline as possible being removed. Then 0.02 to $0.04 \mathrm{ml}$ of $0.1 \%$ Evans blue (EF Nahal and Bray, 1966) was added to the tubes, the larvas were re-suspended for 10 minutes and washed twice with phosphate-buffered saline to remove as much of the Evans blue as possible. The larvae were transferred to a microscope slide with a pasteur pipette for observation. 응

AUTOFLUORESCENCE Eggs of $T$. canis from the stool an uteri gave a non-specific yellow staining both io phosphate-buffered saline and $1 \mathrm{ml}$ phosphate-bufferes saline $+\mathbf{0 . 0 6} \mathrm{ml}$ fluorescein-labelled antihuman globulin the degree of non-specific staining being greater with the latter. The exterior of decoated $T$. canis eggs did not fluoresce but there was some degree of autofluorescence. (greenish-yellow) of both the embryophore and larvare within eggs.

Second stage $T$. canis larvae from mice exhibited na autofluorescence of the cuticle but commonly there wasu yellow non-specific autofluorescence of the gut contents

MICROSCOPY Slides were examined for fluorescent ant 1 은 body staining using a Leitz uniocular microscope and ae air cooled Osram HBO 200 mercury vapour lamp as light source. A BG 12 fluorescence filter and a K530 blue absorption, suppression filter were used. Microscopy wa? done under blue fluorescence (ultraviolet + blue) undeo bright field, illumination. Larvae were also visualize $\overparen{\phi}$ under bright-field, ultra-violet fluorescence using a U.G fluorescence filter and a K430 U.V. absorption, supprese 
sion filter. The endpoint, although arrived at by a subjective estimation, was usually quite clear, being the highest dilution at which distinct staining of the organisms or eggs occurred.

PHOTOGRAPHY Photomicrographs (black and white) were taken with a Leica camera under blue fluorescence (ultraviolet + blue) and ultraviolet fluorescence using a bright field condenser. Colour photographs were taken with Agfa colour, 80 ASA for artificial light.

\section{RESULTS}

Larvae exposed to immune serum, followed by fluorescein labelled antiglobulin gave a bright greenish-yellow fluorescence of the cuticle (Figs. 1, 2 , and 3). Negative or control serum gave no such fluorescence (Fig. 4). The intensity of fluorescence was graded 0 to $3+, 1+$ being faint fluorescence, $2+$ moderate, and $3+$, bright fluorescence. Best results were obtained when larvae were alive or used within three days of recovery from mice. When larvae of this age were used fluorescent precipitates were invariably seen at the orifices of the larvae when they were placed in immune serum. Preservation of the larvae in saline at $-20^{\circ} \mathrm{C}$ rendered them unsuitable for the indirect fluorescent antibody test after six weeks. Preservation at $-20^{\circ}$ $\mathrm{C}$ in $10 \%$ formalin did not render the larvae unsuitable for the indirect fluorescent antibody test, although saline preparations were more sensitive than formalin preparations.

Embryonated and unembryonated decoated eggs in saline showed non-specific staining of the embryophore with a bright green-yellow fluorescence of the outer shell. Evans blue was found not to affect the non-specific staining of the gut contents of the larvae and embryophore of the eggs; it greatly reduced the fluorescence of the decoated egg shell and in most cases obliterated it.

MOTILITY OF T. CANIS LARVAE IN SERUM FROM PATIENTS WITH TOXOCARIASIS OR ASCARIASIS Toxocara larvae recovered from mice have a high degree of motility which is unaffected to any significant degree by incubation at room temperature for 12 hours and at $40^{\circ} \mathrm{C}$ for a similar period either in physiological saline or control serum free from Toxocara or Ascaris antibodies. Sera from patients either with toxocariasis or ascariasis affect motility of the larvae after a few hours and the larvae survive a shorter time, abour 24 hours in Toxocara serum, whereas in sera from patients with ascariasis they died in about 48 hours (Table I).

FLUORESCENT ANTIBODY TEST IN PATIENTS WITH A POSITIVE TOXOCARAL SKIN TEST While a positive toxocara skin test is usually associated with a
TABLE I

EFFECTS OF SERA FROM PATIENTS WITH TOXOCARIASIS OR ASCARIASIS AND FROM CONTROLS AND OF SALINE ON MOTILITY OF T. CANIS LARVAE

Hours of Exposure to Serum

\begin{tabular}{llll} 
Sera & 3 & 24 & 48 \\
\cline { 2 - 4 } $\begin{array}{l}\text { Toxocara } \\
\text { immune sera }\end{array}$ & $3+$ & \pm & 0 (inactive, ?dead) \\
$\begin{array}{l}\text { Ascaris } \\
\text { immune sera }\end{array}$ & $3+$ & $2+$ & 0 (inactive, ?dead) \\
$\begin{array}{l}\text { Control } \\
\text { (negative) sera }\end{array}$ & $5+$ & $3+$ & $\begin{array}{l}+ \text { (feebly active- } \\
\text { dead } 52 \text { hours) }\end{array}$ \\
$\begin{array}{l}\text { Physiological } \\
\text { saline }\end{array}$ & $5+$ & $5+$ & $\begin{array}{l}2+\text { (active-dead } \\
64 \text { hours) }\end{array}$
\end{tabular}

Motility graded 0 to $5+, 0$ being inactive and $5+$ very motile.

positive fluorescent antibody test, about one in five patients with a negative skin test can be expected to give a positive fluorescence test. The results of the toxocaral skin test in patients who had had poliomyelitis (Woodruff, Bisseru, and Bowe, 1966) correlates very closely with those of the immunofluorescent test. By contrast, in patients with asthma correlation is poor. The number of patients in these latter two series is, however, too small to draw firm conclusions (Table II).

\section{TABLE II}

RESULTS OBTAINED WITH THE INDIRECT FLUORESCENT ANTIBODY TEST FOR TOXOCARA USING T. CANIS LARVAE IN HUMAN SERA

\begin{tabular}{|c|c|c|c|}
\hline Patients & No & Positive & Negative \\
\hline Positive toxocaral skin test & 9 & 5 & - \\
\hline Negative toxocaral skin test & 27 & 5 & 22 \\
\hline $\begin{array}{l}\text { Old paralytic poliomyelitis and } \\
\text { positive toxocaral skin test }\end{array}$ & 5 & 5 & - \\
\hline $\begin{array}{l}\text { Asthma, a positive toxocaral } \\
\text { skin test, and negative gelatin } \\
\text { and saline tests }\end{array}$ & 4 & 3 & 1 \\
\hline
\end{tabular}

RELATIVE VALUE OF $T$. CANIS LARVAE AND OVA IN PERFORMING THE FLUORESCENT ANTIBODY TEST For the detection of Toxocara antibodies in human serum the technique employing $T$. canis second stage

\section{TABLE III}

TOXOCARAL ANTIBODIES SHOWN BY INDIRECT FLUORESCENT ANTIBODY TEST IN SERA OF PATIENTS WITH CLINICAL AND SKIN TEST DIAGNOSIS OF TOXOCARIASIS

\begin{tabular}{llll} 
& No. Tested & Positive & Negative \\
\hline$T$. canis larvae & 29 & $10(34 \cdot 5 \%)$ & 19 \\
$T$. canis decoated eggs & 13 & $1(7 \cdot 7 \%)$ & 13
\end{tabular}

Ten out of the 42 patients were tested with decoated $T$. canis eggs without treatment with Evans blue. 


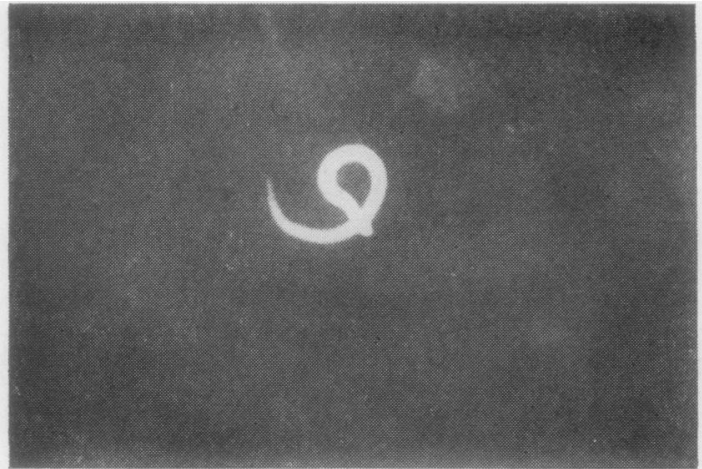

FIG. 1 .

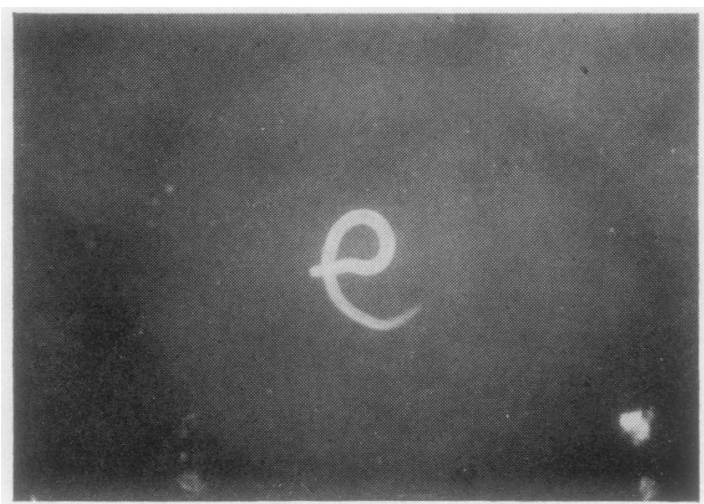

FIG. 2.

Fluorescence photomicrographs stained by the indirect fluorescent antibody method. Serum from a Toxocarainfected patient was used and was followed by fluoresceinlabelled antihuman globulin. In Figures 2 and 6 the black and white reproduction does not show as precisely as colour would the characteristics referred to.

FIG. 1. Fluorescent staining of second stage Toxocara canis larva with serum from an infected patient. Dilution 1/640. Blue fluorescence.

FIG. 2. Same larva as in Fig. 1. Ultraviolet fluorescence. (At the mouth the fluorescent antibody is incorporated into a precipitate.)

FIG. 3. Second stage T. canis larva showing fluorescent precipitate formation around cuticle when incubated with serum from an infected patient followed by fluoresceinlabelled antihuman globulin.

FIG. 4. Second stage T. canis larva showing absence of fluorescent staining when incubated with control (negative) serum followed by fluorescein-labelled antihuman globulin. 
larvae was found to be more sensitive than that in which $T$. canis eggs are used (Table III). In man, it is, of course, infective second stage larvae not the eggs that are the specific antigenic stimulus.

CROSS REACTIONS IN SERA FROM PATIENTS WITH NONTOXOCARAL PARASITIC INFECTIONS As stated earlier, sera from patients with Ascaris lumbricoides infection have been found to give cross-reacting fluorescence with Toxocara larvae as shown in Table IV. The patient with $W$. bancrofti infection was from India and although she had no demonstrable Ascaris infection at the time the positive fluorescence was obtained it is likely to have been caused by an earlier infection.

\section{TABLE IV}

RESULTS OBTAINED WITH THE INDIRECT FLUORESCENT ANTIBODY TEST USING $T$. CANIS LARVAE AS ANTIGEN AND SERA FROM PATIENTS WITH NON-TOXOCARAL PARASITIC INFECTIONS

\begin{tabular}{|c|c|c|c|}
\hline Cther Parasitic Infections & No. & Positive & Negative \\
\hline Ascaris lumbricoides & 3 & 3 & - \\
\hline Schistosomiasis & 2 & - & 2 \\
\hline Onchocerciasis & 2 & - & 2 \\
\hline Hookworm & 1 & - & 1 \\
\hline Trichuris trichuria & 1 & - & 1 \\
\hline Wuchereria bancrof $t i$ & 2 & 1 & 1 \\
\hline Acanthocheilonema perstans & 1 & - & - \\
\hline Taenia saginata & 1 & - & 1 \\
\hline Malaria & 1 & - & 1 \\
\hline Total & 14 & 4 & 10 \\
\hline
\end{tabular}

FLUORESCENT ANTIBODIES IN PATIENTS WITH TOXOCARAL AND ASCARIS INFECTIONS When fluorescence of larvae was observed in Toxocaral serum, some degree of fluorescence persisted even in high dilutions. With highly immune serum concentrations a prozone effect was usually present when the serum was diluted $1 / 10$ or $1 / 20$. This was probably due to the presence of excess antibody, and to prevent the possibility of reporting false negatives if strongly

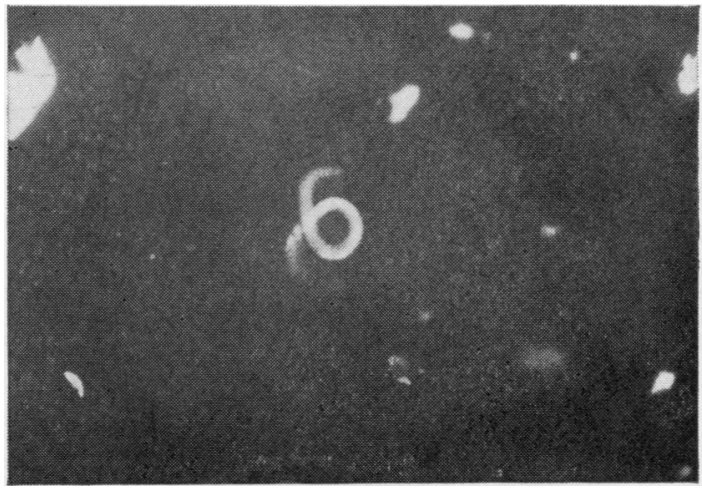

FIG. 5. Second stage larva of $\mathrm{T}$. canis showing crossreacting fluorescence when incubated with serum from an Ascaris-infected patient followed by fluorescein-labelled antihuman globulin. Dilution 1/640. Blue fluorescence.

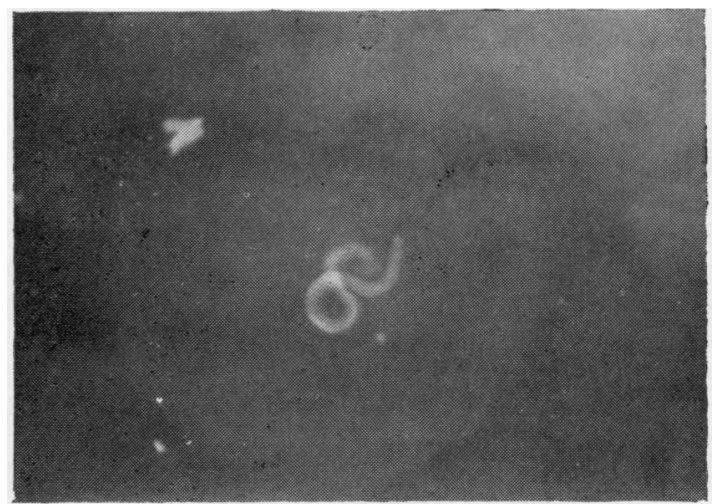

FIG. 6. As in Figure 5. Ultraviolet fluorescence.

reacting sera were tested from patients, a 1/80 dilution of sera was used for routine testing.

When serum from a person with a negative toxocaral skin test (Table V) produced fluorescence,

TABLE V

COMPARISON OF FLUORESCENT ANTIBODY TITRES ESTIMATED BY THE INDIRECT TECHNIQUE USING T. CANIS LARVAE AS ANTIGEN

\section{Dilutions}



Toxocara

Serum from

infected patient

Ascaris

Serum from

infected patient

Control (negative)

serum with 'false'

fluorescence (See

Table II)

$\begin{array}{cccccccccc}+ & 3+ & 3+ & 3+ & 3+ & 2+ & 2+ & 2+ & 2+ & 2+ \\ 2+ & 2+ & + & + & + & + & + & + & + \\ 2+ & 3+ & 2+ & 3+ & 2+ & + & + & + & + & +\end{array}$


TABLE VI

COMPARISON OF FLUORESCENT ANTIBODY TITRES BY INDIRECT TECHNIQUE USING $T$. CANIS LARVA AS ANTIGEN
WITH SERA FROM PATIENTS WITH TOXOCARA AND ASCARIS INFECTIONS
Dilution

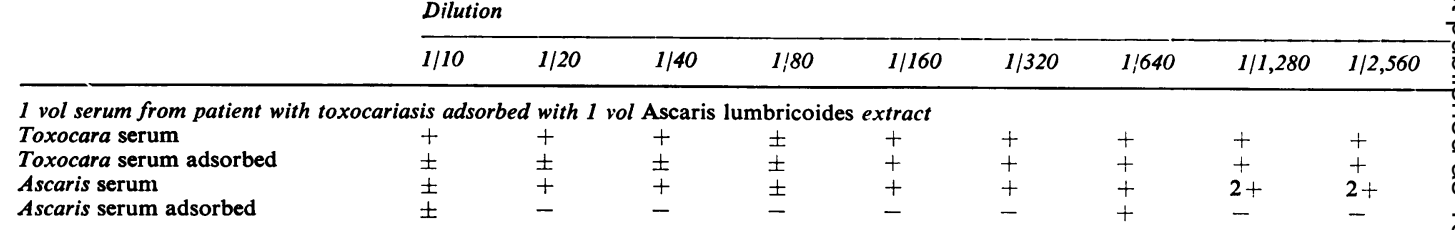

1 vol serum from a patient with toxocariasis adsorbed with 2 vol Ascaris lumbricoides extract

Toxocara serum $2+2+$

Toxocara serum adsorbed

Ascaris serum

Ascaris serum adsorbed

$\begin{array}{ll}2+ & 2+ \\ + & 2+\end{array}$

l vol serum from a patient with toxocariasis adsorbed with 3 vol Ascaris lumbricoides extract

Toxocara serum

Toxocara serum adsorbed

Ascaris serum

Ascaris serum adsorbed

$\begin{array}{cc}- & + \\ \text { (prozone) } & \\ - & - \\ + & +\end{array}$

it was weaker and the endpoint lower (1/320 to $1 / 1,280$ ) than with serum from a patient with toxocariasis.

Using serum from patients with $A$. lumbricoides infections cross reacting fluorescence was obtained with $T$. canis larva (Figs. 5 and 6 ) in high dilutions of serum $(1 / 5,120)$. In view of these observations experiments were undertaken to see whether it was possible to differentiate fluorescence due to Ascaris antibodies from that due to antibodies against Toxocara. For this purpose adsorption of Ascaris antibodies was carried out with the extract of $A$. lumbricoides and when 1 volume of Toxocara serum was adsorbed with 2 volumes of $A$ scaris extract a clear-cut difference was obtained between the sera from the patients with Toxocara and Ascaris infections; the former continued to produce fluorescence only in a $1 / 10$ dilution (Table VI)

\section{DISCUSSION}

The results of the indirect fluorescent antibody test indicate that $T$. canis larvae can be used as antigen in the laboratory diagnosis of toxocariasis. The presence of a prozone effect was often observed with serum dilutions of 1 in 10. This inhibition effect with excess antibody was reported by Sadun et al. (1962) when using rabbit but not human sera in the fluorescent antibody test for the diagnosis of trichinosis. The cuticle of the larva was the site which consistently fluoresced with labelled antihuman globulin when exposed to immune serum. Incorporation of fluorescent antibody was observed sometimes in precipitates seen at the oral orifice of the larvae.
In contrast to the findings of Hogarth-Scott (1966) $T$. leonina larvae recovered from the abdominal wallo of mice showed cross-reacting fluorescence (Fig. 790 in tests with Toxocara immune sera. Serump (dilution 1/40) from two puppies with $T$. canis in fection gave a positive fluorescent reaction with both $T$. canis and $T$. leonina larvae. $T$. canis larvaeo fluoresced considerably showing cross-reaction with serum from $A$. lumbricoides patients although the intensity of fluorescence was weaker in the higher 3 dilutions and the end point lower than with serum? from patients with toxocariasis. This is not sur prising as all the ascarid nematodes are taxono mically related. The metabolic products of theses worms, which are antigenic and stimulate the pro-io duction of antibodies, thus also appear to have. much in common.

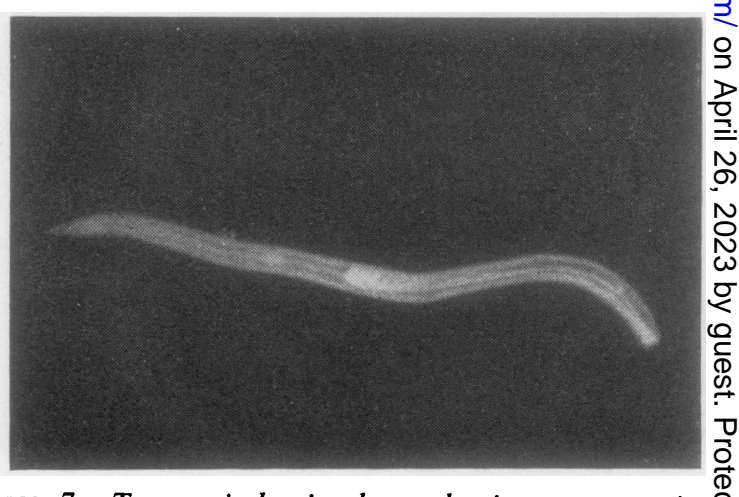

FIG. 7. Toxascaris leonina larva showing cross-reacting $\frac{\overparen{\Phi}}{\Phi}$ fluorescence when incubated with Toxocara-infected $\stackrel{\odot}{\circ}$ patient's serum followed by dilution 1/640. Ultraviolet fluorescence. 
Mitchell (1964), working with monkeys and rabbits, showed that antibodies to $T$. canis can be detected within two weeks of infection and a weak fluorescent reaction was found with sera (anti-Ascaris) from monkeys and rabbits infected with Ascaris suum. Furthermore, Mitchell (1964) found that on routine screening of sera using the indirect fluorescent antibody test with $T$. canis larva five out of 25 children, aged 19 to 22 months, and 17 out of $49(35 \%)$ normal adult blood donors gave a significant fluorescent reaction, and, according to Mitchell (1964), this 'must represent a cross reaction, a persistence of antibody acquired in childhood, or both'.

Our findings to a large extent confirm Mitchell's findings in that five out of $27(19.2 \%)$ normal healthy adults, with a negative toxocara skin test gave a significant fluorescent reaction to high titre $(1 / 1,280)$. Adsorption tests on two of the five sera at a dilution of $1 / 40$, using four times the volume of $A$. lumbricoides 1 in 500 extract, rendered the test negative, ie, the fluorescent antibodies were completely adsorbed by the Ascaris antigen. The adsorption experiments in the work here reported (see Table VI) indicate that specific fluorescence of T. canis larvae in Toxocara and Ascaris immune sera is based on a true antigen-antibody reaction and by varying the concentration of antigen against a fixed volume of serum all the fluorescent antibodies are adsorbed. In the present investigations 3 volumes of $A$. lumbricoides ( 1 in 500) extract adsorbed all Toxocara antibodies from 1 volume of Toxocara serum, whereas 2 volumes of Ascaris extract adsorbed all Ascaris antibodies from 1 volume of serum from a patient with toxocariasis leaving sufficient toxocaral antibodies to give a satisfactory fluorescent antibody test (Table VI).

The results of the Toxocara indirect fluorescent antibody test as outlined above show that 'false' positive results as seen in some patients are probably due to circulating Ascaris antibodies which can be removed by adsorption tests. In the British Isles and Europe, $A$. lumbricoides infection is rare in comparison with the tropics and the indirect fluorescent antibody test may be usefully employed for the detection of toxocariasis in man. The toxocaral skin test is more specific than the fluorescent antibody test and does not give any appreciable number of positive reactions in patients with present or past $A$. lumbricoides infections (Woodruff and Thacker, 1964).

The indirect immunofluorescent test which we have used has the advantage that all the reagents except second stage Toxocara larvae are commercially available and that they are easily obtained from mice by feeding them large numbers of embryonated $T$. canis eggs. The latter so obtained a number of sera can conveniently be tested at any one time using a $1 / 80$ dilution of patient's serum. The test might also prove of value in survey work aimed at detecting the incidence of toxocariasis in man and using for the purpose serum obtained from blood by finger pricking.

We are indebted to the Medical Research Council to whom we express our thanks for a grant which has made this study possible. We also thank Mr L. E. Pettitt and Mr A. I. Shah for valuable technical assistance and Mr C. J. Webb for the photographs.

\section{REFERENCES}

Anderson, R. I., Sadun, E. H., and Williams, J. S. (1961). Exp. Parasit., 11, 226.

Bisseru, B., Woodruff, A. W., and Hutchinson, R. I. (1966). Brit. med. J., $1,1583$.

El-Nahal, H. M. S., and Bray, R. S. (1966). Trans. roy. Soc. trop. Med. Hyg., 60, 564.

Hogarth-Scott, R. S. (1966). Immunology, 10, 217.

Jackson, G. J. (1959). J. infect. Dis., 105, 97.

Mitchell, J. R. (1964). Proc. Soc. Expr. Biol. Med., 117, 267.

Sadun, E. H., Anderson, R. I., and Williams, J. S. (1962). Exp. Parasit., 12, 423.

—, Williams, J. S., and Anderson, R. I. (1960). Proc. Soc. exp. Biol. (N.Y.), 105, 298.

Taffs, L. F., and Voller, A. (1963). Trans. roy. Soc. trop. Med. and Hyg., 57, 353.

Voller, A., and Taffs, L. F. (1962). Ibid., 56, 2.

Woodruff, A. W., Bisseru, B., and Bowe, J. C. (1966). Brit. med. J., $1,1576$.

—_, and Thacker, C. K. (1964). Ibid., 1, 1001. 